\title{
REAL VERSUS FICCְÃO: \\ CRIANÇA, IMAGEM E REGIMES DE CREDIBILIDADE NO CINEMA-DOCUMENTÁRIO
}

Fabiana de Amorim Marcello*

RESUMO: O objetivo deste artigo é discutir a organização imagética do gênero documentário a partir de dois materiais que colocam em evidência a imagem da criança: Promessas de um Novo Mundo (2001), de Justine Shapiro e B. Z. Goldberg, e Nascidos em Bordéis (2004), de Ross Kauffman e Zana Briski. O que importa aqui é trazer para a educação um debate contemporâneo sobre as imagens que nos cercam cotidianamente, especialmente quando têm como mote a narrativa sobre a infância. Assim, num primeiro momento, são apresentados alguns elementos da constituição dessa linguagem específica. Em seguida, passa-se à análise dos filmes em questão e, em especial, à forma como são dadas as relações de veracidade a partir das imagens e da construção das respectivas narrativas. Paralelamente a isso, discute-se, mais amplamente, sobre imagens que nos fazem pensar na medida em que colocam, lado a lado, crianças, abandono, miséria e morte.

Palavras-chave: Educação; Criança; Cinema; Imagem.

REAL VERSUS FICTION:

CHILD, IMAGE AND CREDIBILITY REGIMES IN DOCUMENTARY MOTION PICTURES

ABSTRACT: The purpose of this article is to discuss the issues related to the image organization of the documentary genre based on two materials that emphasize the image of the child: Promises (2001), by Justine Shapiro and B. Z. Goldberg and Born into Brothels: Calcutta's Red Light Kids (2004), by Ross Kauffman and Zana Briski. Firstly, I expose some elements of the constitution of that particular language, as well as some of the changes that were and are being made in this film genre. Then I move on to the analysis of the aforementioned films and, in particular, the way the relations of credibility derived from the images and the construction of their corresponding narratives take place. Parallel to this, as I believe such materials offer us more than the real versus fiction dialogue, I discuss, more broadly, the images that make us think when they place, side by side, children, abandonment, poverty and death. This is about lives, unique stories that would certainly be destined to be forgotten and erased, but, captured by the motion picture camera, invite us to see that there is more to it, there is dignity and art.

Keywords: Education; Child; Movie; Image.

\footnotetext{
* Doutora em Educação pela Universidade Federal do Rio Grande do Sul (UFRGS); Professora do Programa de Pós-Graduação em Educação da Universidade Luterana do Brasil (ULBRA) e Membro do Núcleo de Pesquisa em Mídia, Educação e Subjetividade (NEMES). E-mail: famarcello@uol.com.br
} 
Real versus ficção:

criança, imagem e regimes de credibilidade ${ }^{1}$ no cinema documentário

O gênero documentário talvez seja o tipo de produção fílmica que coloca em jogo, de forma mais pontual, a dualidade entre "real" e "ficção". De certa forma, ele tensiona o próprio conceito de ficção (justamente por afirmar-se como seu oposto), da mesma maneira que a fotografia viria a fazer em relação à pintura em meados do século XIX. Ou talvez possa se dizer que ele revigora, pelo menos entre o senso comum e por outros modos, caminhos anteriormente percorridos quando da invenção do cinematógrafo e dos múltiplos entendimentos, em termos de linguagem, sobre o cinema como "testemunha do mundo".

O "cinema do real" encontra-se predominantemente assimilado a uma ideia geral de produção de imagens mais "puras", que atuariam, supostamente, como uma espécie de reflexo fiel do mundo (o mundo, digamos, "tal como ele é"). Ainda assim, as imagens criadas na rede narrativa do documentário funcionariam, também supostamente, como testemunhas de uma realidade que, a princípio, lhes seria preexistente. A câmera testemunhal, "objetiva", no lugar de uma câmera que seria intencional e autoral, imagens que "falam por si mesmas", no lugar de um ponto de vista construído, pensado, organizado em torno de fatos, pessoas e coisas (MAIXENT, 2003, p. 165, tradução minha).

Neste artigo ${ }^{2}$, meu objetivo é discutir as questões que tangenciam a organização imagética do gênero documentário a partir de dois materiais: Promessas de um Novo Mundo (2001), de Justine Shapiro e B. Z. Goldberg, e Nascidos em Bordéis (2004), de Ross Kauffman e Zana Briskidocumentários que colocam em evidência a imagem da criança e que, portanto, convidam-nos, pesquisadores do campo da Educação, a pensar e debater sobre questões urgentes do nosso tempo. Num primeiro momento, apresento alguns elementos da constituição dessa linguagem específica, bem como algumas das alterações que foram e vêm sendo feitas no âmbito desse gênero fílmico. Em seguida, analiso esses filmes e a forma como nos são dadas as relações de veracidade a partir das imagens e da construção das narrativas. Paralelamente a isso, e por acreditar que tais materiais nos oferecem mais do que o jogo real versus ficção, discuto sobre imagens que nos fazem pensar, ao colocar, lado a lado, crianças, abandono, miséria e morte. Trata-se de vidas, de histórias singulares que certa- 
mente estariam destinadas a ser esquecidas e apagadas, mas que, alçadas pela câmera cinematográfica, nos convidam a ver que há ali mais do que isso, há ali dignidade e arte.

\section{Cinema-documentário e os regimes de credibilidade da imagem}

Dziga Vertov foi um dos primeiros cineastas a sistematizar acerca da capacidade da câmera cinematográfica como instrumento de captura do "real". Vertov acreditava na capacidade da câmera como elemento de ultrapassagem do olho humano (este sempre carregado de intenções); mais do que isso, ele punha o olho humano em oposição ao cine-olho. Este último, mais aperfeiçoado que o primeiro, sem suas intenções subjetivas, teria como captar "tudo aquilo que podia servir para descobrir e mostrar a verdade" (VERTOV, 2003, p. 262-263, grifos do autor).

Por mais que a ideia pareça hoje ultrapassada no âmbito do cinema, ela reincide na crença de que a imagem seria uma espécie de superfície lisa, uniforme e, ao mesmo tempo, opaca e, em certa medida, misteriosa, na qual a câmera e o olhar testemunhal do cineasta viriam a atingir (ou pelo menos a buscar) uma luminosidade ascendente. Trata-se de uma espécie de crença absoluta, do convite à adesão a uma imagem em seu "estado bruto", como se fosse possível estabelecer daí uma "religião", uma relação de fé: a coisa na imagem e, consequentemente, na condição de imagem, a coisa falaria de si mesma. Ora, as crenças e afirmativas mais comuns sobre a produção do documentário reiteram, em grande parte, essas assertivas - semelhante àquelas que, mais tarde, viriam a operar na também religiosa adesão ao "eu vi no telejornal" e àquela a que somos convidados, por exemplo, pelas imagens "ao vivo" na televisão.

O documentário como tal tem sua história exatamente em meio às novas possibilidades oferecidas pela câmera. Isso implica afirmar que o documentário não teve suas origens anos depois da invenção do cinematógrafo, anos depois do surgimento de filmes tidos como "ficcionais". O documentário nasce, ele mesmo, com o cinema, junto ao cinema: Saída dos Trabalhadores das Fábricas Lumière ou A Chegada do Trem na Estação - os primeiros filmes dos irmãos Lumière - estão muito próximos do valor documental das imagens; muito próximos, portanto, desse gênero a que chamamos documentário. Porém, o investimento nessa capacidade inicial de 
“reprodução do real" e a exploração de uma linguagem específica (aliadas a uma habilidade comercial que lhe deram bases institucionais) fizeram com que, em meados dos anos 1920, o documentário, enfim, se diferenciasse de outros gêneros e assumisse estatuto próprio.

O "pai do documentário", Robert Flaherty, introduz, nesse período, a prática do documentário "encenado". No célebre Nanook, o Esquimó (1922), o cineasta filma a vida de um esquimó inuit - Nanook no interior do Alaska. Cenas que aparentemente se davam dentro de um iglu eram de fato filmadas ao ar livre para que fosse possível uma melhor captação de luz; cenas triviais do dia a dia esquimó, que iam desde a preparação dos alimentos aos momentos de refeição propriamente ditos, e mesmo situações de caça, eram reconstituídas (e muitas vezes inventadas, como a captura de um lobo marinho - algo que Nanook nunca havia feito). Tais cenas não tinham como objetivo ser o resultado direto de um acompanhamento rigoroso do cotidiano - o que hoje se torna marca nesse tipo de produção. As imagens do dito "real" de Flaherty eram uma "encenação" dos hábitos e não sua imediata efetivação "original” frente à câmera e, em função disso, avaliadas por alguns como "métodos 'inescrupulosos" (DI TELLA, 2005, p. 73).

A ideia da câmera como uma "mosquinha na parede", que captava imagens e registrava fatos como se não estivesse ali, ganhou primazia com o documentário moderno. Essa modalidade de organização documental teve seu início na década de 1960, no âmbito americano, em meio à ilusão da possibilidade de se fundar um "cinema direto", baseado numa intervenção mínima do diretor e na reprodução da "realidade tal como ela é” (DI TELLA, 2005, p. 73). Tal crença tornou-se possível, sobretudo, com o advento da tecnologia da fabricação de equipamentos de captação de imagens e sons: câmeras portáteis, mais leves, e que eram capazes também de capturar as imagens sincronicamente aos sons tornaram a filmagem, de certa forma, mais independente de todo o aparato cinematográfico das grandes produções.

Nesse mesmo período, fervilhava na França o cinéma verité, que tinha como pioneiro o etnógrafo Jean Rouch. Diferente das concepções mais objetivas da produção do documentário (formuladas pela noção americana de "cinema direto"), o cinéma verité não partia de um princípio de invisibilidade ou indiferença frente à câmera (seja por parte do documentarista, seja por parte dos personagens que ele convoca). Para Rouch, 
o documentário não revelaria a realidade stricto sensu, mas “a realidade de um tipo de jogo que se produz entre as pessoas que estão à frente e atrás da câmera" (DI TELLA, 2005, p. 76).

Obviamente que, por mais que algumas dessas ideias persistam, elas vêm sendo cada vez mais questionadas no interior de discussões do domínio do campo do cinema-documentário. Como diz Rabiger (2005, p. 62), "acredito que todas as histórias - ficcionais ou de documentários envolvem um drama”. Isso implica supor que o documentário, como qualquer outra narrativa, gira em torno dos ingredientes clássicos da dramaturgia: "os personagens, suas necessidades, o que estão tentando fazer ou conseguir, o que os está impedindo, como eles lutam para obter ou fazer, como suas listas são resolvidas, e quem cresce em conseqüência disso" (RABIGER, 2005, p. 62).

Sabe-se que entre a câmera e as pessoas entrevistadas num documentário ou entre a câmera e o cineasta que a conduz "sempre há atuações” (DI TELLA, 2005, p. 72). Entre a câmera e o entrevistado há um paradoxo que envolve a mais óbvia atuação (dos gestos, das falas pensadas, devidamente articuladas), mas também o espaço de novidade que, sem a filmagem, dificilmente seria produzido. "A consciência de que estamos filmando gera no sujeito uma entrega de si dificilmente possível sem o compromisso com o ato documental" (DI TELLA, 2005, p. 73). Entre a câmera e o cineasta, a atuação se dá, por exemplo, no nível da provocação para obter certas respostas e certos efeitos dos personagens-entrevistados (como na proposição de perguntas cujas respostas já seriam de seu conhecimento, mas que, para efeito de imagem, teriam de ser ditas como se o fosse pela primeira vez) (DI TELLA, 2005).

O que os documentários colocam em jogo é a "verdade" e o "real", um real que, entendo aqui, existe não diretamente na imagem, mas na relação que estabelecemos com ela (o que significa apostar naquilo a que somos por ela convocados) e que, aos nossos olhos, se faz verdadeira e fruto da realidade. Assim, minha intenção neste texto é fazer jus àquilo que tão claramente nos escreve Ismail Xavier, ao dizer que "toda leitura de imagem é produção de um ponto de vista: o do sujeito observador, não o da 'objetividade' da imagem" (XAVIER, 1988, p. 379). O real da imagem está ligado às formas de sua construção e, sobretudo, às formas por meio das quais damos sentido e valor a ela - ato, por si só, puramente pedagógico. 


\section{Dos regimes de credibilidade do cinema-documentário em}

\section{Nascidos em Bordéis e Promessas de um Novo Mundo}

Um grupo de sete crianças (árabes e judias) prestam depoimentos sobre a guerra da qual também fazem parte. A quem pertence o território de Israel? O que sentem ao verem amigos e familiares perderem suas casas e mesmo suas vidas? As respostas a essas questões são acompanhadas, paralelamente, pela tentativa de um encontro entre ambas - que, por mais que vivam a 15 minutos uma das outra, encontram-se distantes, espremidas entre o rancor de um conflito que dura mais de 50 anos e a prolixidade dos discursos de paz que invariavelmente também as atingem. Por outro lado, no Distrito da Luz Vermelha, em Calcutá, acompanhamos o cotidiano de meninos e meninas filhos de prostitutas que, desde cedo, convivem com a miséria, com a pobreza e com a condição de serem cidadãos de segunda classe. Ao mesmo tempo, convidados por uma fotógrafa (Zana, também uma das diretoras do filme), eles têm aulas de fotografia, manuseiam câmeras, registram seu cotidiano e cedem outro olhar para aquilo que veem todos os dias. A partir dos filmes Promessas de um Novo Mundo e Nascidos em Bordéis, gostaria de discutir a presença de um conjunto de elementos que participam da construção desse "real" de que falei anteriormente ou, mais diretamente, de como se estabelecem aqui os regimes de veracidade ou de credibilidade da imagem documental.

Inicialmente, poderíamos até destacar alguns elementos que repousariam numa concepção mais clássica das características gerais do documentário: a ausência de atores, ausência de cenários previamente organizados, presença de especialistas que outorgariam os ditos, presença de imagens de um arquivo histórico, entre outras (NICHOLS, 2007). Contudo, sabe-se que muitas dessas características sofrem hoje um duplo movimento de crítica e de relativização.

O surgimento de novos documentários e as invenções que são tramadas nesse campo vêm, nos últimos anos, a tornar senão inválida, pelo menos duvidosa a caracterização do documentário por meio desse conjunto de elementos. Apenas para citar um exemplo, o documentário lançando recentemente por Eduardo Coutinho, Jogo de Cena (2007), nos coloca à prova tanto a representação de atrizes e não-atrizes quanto a veracidade de depoimentos e histórias pessoais. Convidadas por um anúncio de jornal publicado pelo diretor (sequência inicial do filme), mulheres 
anônimas são colocadas ao lado de atrizes como Marília Pêra, Andréa Beltrão e Fernanda Torres (entre outras atrizes, para o público geral, desconhecidas). Cada uma das mulheres (personagens?) conta histórias pessoais ou continua contando uma história da personagem mostrada anteriormente, a ponto de não sabermos mais se são as atrizes que interpretam as histórias das anônimas ou se são as anônimas que interpretam as histórias das atrizes.

O que vemos com isso é que

a credibilidade de uma imagem, de uma situação, de um momento do cinema, não tem nada a ver com os gêneros codificados da ficção ou do documentário. A ficção pode produzir o verdadeiro e o documentário o falso. O que mais vale é o regime de credibilidade organizado por este ou aquele filme do que o pertencimento deste a este ou aquele gênero (MAIXENT, 2003, p. 168, grifos meus, tradução minha).

O que podemos, no entanto, é examinar que outras formas de veracidade são estabelecidas por esses materiais. Ou, usando as palavras do autor, perguntar sobre os "regimes de credibilidade" elaborados pelos filmes, lembrando que, para tanto, há sempre, entre nós e a imagem, um apelo à participação, um jogo que só se joga porque a relação entre imagem e espectador jamais é unilateral. No caso dos documentários em questão (Nascidos em Bordéis e Promessas de um Novo Mundo), esses regimes dizem respeito, especialmente, a três movimentos: o encadeamento nãosistemático, mas visível, entre causas e consequências dos fatos; a utilização não de especialistas para conduzir a narrativa ou afirmar a veracidade dos dados, mas de "gente como nós"; e, por fim, o apelo a um elemento comovente, qual seja, a relação criança versus futuro.

No que diz respeito ao primeiro aspecto, o que se entende por encadeamento de causas e consequências? Tal encadeamento diz respeito à apresentação de conclusões que não são dadas pelo comentário direto do cineasta, nem mesmo como resultado de entrevistas entre os personagens, mas que, ao mesmo tempo, concorrem (talvez por afirmarem) com aquelas que, de algum modo, já temos antes mesmo de assistir às imagens. Por um lado, a luta entre israelenses e árabes que não leva senão à desgraça e à tragédia de vidas, acompanhada da exposição de sistemas religiosos e práticas conservadoras que contribuem para a manutenção das posições, e não para seu questionamento. Por outro, na Índia, o descaso com as 
crianças, com um espaço geográfico instalado entre os becos e a prostituição, o sistema cruel de uma burocracia desorganizada, que, entre outras coisas, não permite, por exemplo, que uma criança aidética tenha a chance de se matricular numa escola (quando, sabe-se, a Índia é um dos países mais assolados pela doença).

O que gostaria de trazer para o debate não é se tais conclusões são verdadeiras ou mentirosas, nem mesmo apontar para uma suposta intencionalidade para que sejamos apresentados (ou não) à opinião daqueles que produziram o material. O que interessa é perceber de que maneira o documentário se organiza a partir de um encadeamento de conclusões que não estão lá, dadas e localizadas nesta ou naquela sequência. Ou seja, o que digo aqui e que se torna visível pelo conjunto da narrativa não é fruto de um comentário explícito, nem mesmo encontrado diretamente na imagem. Ainda que o espectador participe solidariamente do processo, há estratégias adotadas na realização do filme para que isso seja possível. Tomemos, a título de exemplo, apenas um "recorte" (dos tantos possíveis): a indignação de Zana, sua corrida incansável pela matrícula de todos os alunos; todas as dificuldades e obstáculos por ela enfrentados para colocar as crianças na escola. $\mathrm{Na}$ condição de telespectadores, aguardamos apreensivos, junto com Zana, o resultado dos testes de HIV daqueles meninos e meninas; perturbamos-nos com uma câmera inquieta que filma o caos de papéis do cartório do Distrito; comovemos-nos com a leveza com que as crianças tiram seus retratos $3 \mathrm{X} 4$ para compor suas fichas de inscrição nas escolas; acompanhamos Zana pelas escolas e suas resistências, e isso mediante um tipo de imagem semelhante àquelas "ao vivo" (com hesitações, com depoimentos e rostos fora do enquadramento, etc.), enfim, somos convocados a uma miscelânea de sentimentos - só possível mediante um entrelaçamento preciso de idas e vindas, derrotas e vitórias, conquistas e perdas. Trata-se de estratégias e de um repertório de ideias que vão sendo estabelecidos e tecidos também por nós, espectadores, e que contribuem para a construção do verídico. O que importa, portanto, é a nossa participação nesse processo. Ou, em outras palavras: como questionar a credibilidade de algo que eu mesmo conduzo, porque solidário à sua constituição?

O segundo aspecto da composição do "real" dado pelas imagens dos filmes diz respeito, nesses materiais, à apresentação dos fatos via pessoas como "nós", mas com um diferencial decisivo. Em ambos os docu- 
mentários, o elemento condutor da narrativa - o narrador-diretor, presente seja na voz em off, seja no diálogo com os personagens que compõem a trama - são, ao mesmo tempo, "nós" e "eles". Em que sentido? Eles são "nós" porque, de certa maneira, nos identificamos com aquelas pessoas, que, num caso, saíram do ambiente da guerra judaico-palestina, não moram mais ali, naquele espaço, e muito menos são vítimas diretas das consequências do conflito. No outro caso, a fotógrafa é aquela que procura dar uma nova oportunidade de vida àquelas crianças a partir da arte da fotografia (que ensina a elas por meio de aulas não-sistemáticas), como também busca avidamente que aquelas crianças possam ter acesso à escola. Eles são "nós" porque se espantam com aquela realidade, não a aceitam e, cada um a seu modo, na distância que lhes caracteriza, mostra as possibilidades e impossibilidades de reversão desse fato.

Contudo, tanto o documentarista quanto a diretora-fotógrafa são também "eles": é o judeu que teve sua infância em Jerusalém, que diz ter vivido lá uma infância "normal" - normal que, como explica, em se tratando de Oriente Médio, significava conviver com a guerra; ou seja, o judeu que volta depois de anos para Israel e dali nos narra o conflito com a ajuda das crianças. Como pertencente àquele universo, ele sabia que "as crianças tinham algo a dizer, mas ninguém lhes perguntava o que pensavam do conflito ou dos processos de paz". De forma semelhante, a fotógrafa que não apenas aparece ali, no bairro de prostituição indiana, para filmar; trata-se de uma voluntária que há anos exerce um trabalho naquela comunidade. De fato, ela se aproximou das mulheres para conhecer e para fotografar a vida delas, mas foram as crianças que a "apaixonaram". "Eles" e "nós" conjugam-se em um só personagem (ou dois, um em cada documentário) e, consequentemente, organizam a junção de duas estratégias que geralmente se encontram separadas no domínio do documentário: "eu falo deles para vocês" e "eu falo - nós falamos - de nós para vocês".

Por fim, o terceiro aspecto de organização da veracidade presente nos filmes diz respeito à conclusão, que também não é dada imediatamente na tela, da crueldade de crianças cujas possibilidades de ser algo diferente do que são lhes foram amputadas. Em troca, outro futuro, talvez pronto, talvez previsível e, por que não dizer?, chocante, lhes é dado. Futuros que são expressos pelas palavras tão bem-organizadas das crianças, ideias prontas, extraídas de suas certezas a respeito de a qual povo, afi- 
nal, pertence o território de Israel. Nas palavras "maduras" das crianças, naqueles textos baseados na página exata do Alcorão, que diz que o território pertence aos árabes, ou nas folhas da Torá, que afirma a posse por parte dos judeus, vemos o futuro de uma guerra certa e de um ódio que se perpetua. Um futuro por vezes descrito em seus mínimos detalhes, a ponto de se parecer mais com um mero conjunto de compromissos dispostos numa agenda, talvez a serem cumpridos no dia seguinte: "Quando eu for grande e for mãe, vou pôr a mesa. Vou cozinhar e ter convidados. Depois, vou descansar. E depois acender as velas e ir até a sinagoga. E aí, a gente vai ter um jantar de Sabá, uma aula de Torá. De manhã, vamos de novo para a sinagoga. E vou descansar com o meu marido. Depois vou almoçar e passear com as minhas amigas. Vamos levar as crianças no parquinho e sentar no banco. E quando o sol se puser, voltamos para casa e comemos a terceira refeição". A menina judia diz essas frases de forma tão decidida, e tenta, ao mesmo tempo, separar duas cadeiras de plástico na cozinha de sua casa, ironicamente presas entre si. Em Nascidos em Bordéis, a sina das mulheres à prostituição, as gerações compostas, muitas vezes, por bisavós, avós, mães e filhas que nos são oferecidas ao olhar por imagens granuladas, avermelhadas e desfocadas, tanto pela câmera do cineasta quanto pelas fotos produzidas pelas crianças. Vemos ali, nas meninas, a herança que as famílias podem lhes dar.

O que essas discussões nos mostram é o investimento na crença sobre aliança entre criança e futuro. $\mathrm{O}$ que nos comove não é a reversão dessa crença, mas a aposta na possibilidade de que o futuro seja outro, não tão duro e cruel. A narrativa, em si, não é mais "real" do que outras, chamadas "ficcionais", mas resultado de um conjunto discursivo específico, que aqui encontra seus ecos no apelo genuíno entre a criança e a modificação do curso da história. Não afirmo que os filmes façam só e exatamente isso - e falaremos sobre essa relação mais detalhadamente a seguir -, mas as narrativas seguramente contemplam tal aliança.

$\mathrm{Na}$ análise que faz sobre o filme brasileiro Cidade Baixa, Maria Rita Kehl (2005) questiona a marca que tem sido cada vez mais comum nos filmes produzidos no Brasil - e que talvez também seja visível em outros, de outras nacionalidades: a lógica do "soco no estômago". Diz a autora que "esperamos a carnificina, esperamos gozar de aflição ante a imagem terrível que é, sempre, a de um homem morrendo pela mão do semelhante". Não há dúvida de que Promessas de um Novo Mundo e Nascidos 
em Bordéis operam com essa lógica. As imagens telejornalísticas da guerra tecidas junto aos comentários das crianças judaicas e árabes, somadas àquelas que mostram as visitas ao cemitério onde está enterrado o amigo com o qual brincavam, fortalecem e sustentam tal lógica. Da mesma forma, encarar a mulher prostituta no quarto com seu cliente e, ao lado, a filha que olha para a janela (e que diz: "a vida que a gente leva não permite que a gente realize nossos sonhos") nos agride de forma áspera. Kehl pergunta-se, ainda, "por que essa expressão se tornou um elogio ao cinema: por que nós, espectadores, gostamos tanto de levar socos no estômago?” (2005, p. 1). Terminado o filme, talvez fiquemos com a impressão de que "ainda bem que estamos longe", como se o fato de acompanhá-lo de nossas casas nos expurgasse da total passividade e mesmo impotência frente ao universo devastador. No entanto, talvez o "soco no estômago" nos atinja porque, antes de mais nada, ele fale um pouco de nós mesmos e também da nossa dificuldade, genuína por certo, em digerir imagens de crianças que já têm seu futuro traçado, previsto, mesmo que insistam e se encantem com a criança que passa ao lado e diz saber "ler as mãos" curiosas, as crianças oferecem suas mãos à menina, como se elas já não soubessem o que as aguarda, como se pudessem ou se quisessem fugir daquilo, nem que seja pela ilusão da quiromancia. Que curiosidade é essa sobre aquilo que já sabem? Que curiosidade é essa, vital, que as faz esquecer, por um momento, da frase dita há alguns instantes, segundo a qual "há que se aceitar que a vida é triste e dolorosa"?

Colocar a discussão nessas bases implica assumir que o gênero documentário não traz imagens mais ou menos "reais", já que "todos os grandes filmes tendem ao documentário, como todos os documentários tendem à ficção. [...] Quem opta por um necessariamente encontra o outro no final do caminho" (GODARD, 1985, p. 144, tradução minha). Obviamente isso não quer dizer, de modo linear, que tais materiais estejam falando de outra que coisa que não sobre o conflito árabe-judeu ou da vida humilhante no Distrito da Luz Vermelha, na Índia. Elencar os mecanismos de composição de uma linguagem específica não significa afirmar que os documentários em questão apostariam numa prática manipulatória. Significa tão-somente apostar que as imagens que ele traz não são representações diretas de um real que lhe seria anterior. 


\section{Nascidos em Bordéis e Promessas de um Novo Mundo: para além dos limites de veracidade da imagem documental}

Seguramente, os documentários em questão não se resumem a estabelecer regimes de credibilidade. Esse é um de seus aspectos, mas não o único. No que se refere diretamente à análise da imagem da criança, importa destacar a forma como algo ali escapa e ultrapassa a veracidade posta em jogo pelas imagens, como algo ali foge da mera atribuição do "isto é" (FISCHER, 2006, p. 64). Os depoimentos dados pelas crianças e mesmo a própria organização do material nos convidam a pensar outras relações entre criança e imagem, criança e cultura; relações que vão além do olhar condescendente para as vítimas de guerra e da pobreza ou do sentimento piedoso para aquelas que parecem ter a vida inteiramente traçada. O menino árabe loiro, de olhos verdes, bem como os gêmeos judeus que, por não serem religiosos, têm medo de se aproximar da mais sagrada área judaica, o Muro das Lamentações, nos dão algumas pistas mais imediatas desse movimento que excede as generalizações.

Tal como Rosa Fischer descreve em relação aos meninos infames de Cidades de Deus, da mesma forma as crianças dos dois filmes nos são apresentadas na sua condição de "existências-clarão" (FOUCAULT, 2003; FISCHER, 2006) e que não deixam de ser também "poemas-vida", porque singulares e humanas. Existências que certamente estavam destinadas a não deixar rastros e a ficarem confundidas na grande massa amorfa que hoje chamamos das mais variadas formas: "judeus, "árabes", "indianos", "terroristas", "prostitutas". Também aqui "vidas singelas, insignificantes, por vezes infames, recebem o olhar das lentes do cinema, e nos são oferecidas ao olhar" (FISCHER, 2006, p. 59). Mas não um olhar qualquer, senão aquele distante do "consenso, medido por roteiros padronizados e fórmulas dualistas, através dos quais se deseja tocar nas feridas sociais sem correr o risco de perder a audiência" (FISCHER, 2006, p. 59).

Somos convidados a ver mais, a ver além, tal como as próprias crianças do Distrito da Luz Vermelha, a quem a fotógrafa-diretora fornece câmeras fotográficas para novas descobertas daqueles mesmos becos cotidianos, dos mesmos rostos familiares e da mesma degradação humana. Somos convidados a ver a criança que instaura um vazio em nossas certezas e também em suas próprias. Por um lado, a aproximação entre crianças judias e árabes, propiciada pela produção do documentário. Um 
encontro que tem a ver com curiosidade - mas que nos leva a perguntar: que curiosidade é essa em relação àquilo sobre o qual eles não cessam de falar (o outro, o árabe, o judeu) e aparentemente parecem já ter delineado? O momento esperado envolve uma delicada preparação: acompanhamos especialmente Faraj, o menino árabe, na arrumação cuidadosa da casa, seu banho, seguido do penteado meticulosamente esculpido com gel, a roupa nova e o perfume. Tudo isso pautado pela canção tipicamente árabe que toca no rádio e por sorrisos de excitação.

Como todo encontro com o desconhecido, também nesse não são pequenas as dificuldades a se enfrentar. Primeiro, dificuldades de movimento: há que se transpor os postos de fiscalização israelenses que separam e cercam Jerusalém das regiões vizinhas. Já que é mais difícil para os árabes passarem pelo exército, sãos os meninos Yarko e Daniel, judeus, que vão ao encontro de Faraj e Sanabel, até o campo de refugiados onde moram. Dificuldades mesmo de língua: o árabe que não fala hebraico e o judeu que não fala árabe devem agora manter a comunicação numa língua comum, na qual ainda são pouco fluentes (o inglês).

Um encontro também nem por isso menos cercado de medos, receios e tristeza. Medo de adentrar literalmente no "território inimigo", medo de tocar em assuntos tão delicados para ambas as partes ("Podemos falar de esportes com ele, política, não", diz o Yarko; "Você não pode fugir de tudo sempre", responde o irmão, Daniel). Receio de falar em hebraico em pleno campo de refugiados na Cisjordânia, ao lado de muros pichados pelo Hamas e em meio às marcas indeléveis da Intifada. Tristeza que, após terem passado um dia inteiro juntos, faz o menino árabe perguntar: "O que vai ser da nossa amizade quando o filme terminar?"

Promessas de um Novo Mundo não preconiza a amizade óbvia e dada entre as crianças - fazer isso significaria resumir as potencialidades em jogo e lançar tudo para a ordem do mesmo: em vez de os "judeus", os "árabes", seriam apenas as "crianças" e as universalidades que as cercam. Ao contrário, sutilmente percebemos que há crianças judias que não se propuseram encontrar crianças árabes e vice-versa. E, mesmo após o encontro, observamos que pouco restou do futebol que jogaram e do almoço compartilhado. Da mesma forma, o documentário não segue o caminho fácil de comprometer as crianças com a possibilidade de paz, nem mesmo responsabilizá-las por aquilo que efetivamente pensam sobre o povo oponente. O que o filme faz é instaurar um espaço entre esse com- 
prometimento e essa responsabilização: um espaço no qual nem o futuro concentra-se nas mãos das crianças (seja ele a favor da paz ou não), nem se limita a mostrá-las como resultados diretos daquilo que há anos lhes vem sendo ensinado. Seria ingênuo supor que não há tais assertivas e que elas não sejam tornadas visíveis pelas imagens e pelos depoimentos. Certamente que sim, mas há também esse espaço entre a previsibilidade e a "conscientização".

De forma mais ampla, talvez possamos dizer ainda que esse espaço é aquele no qual é instaurada, mesmo que brevemente, uma suspensão do "isto é": isto é a criança que não vê diferença entre culturas, que naturalmente brinca e que faz amigos; "isto é" a criança a quem podemos confiar um futuro melhor e, igualmente, "isto é” (ou são) os judeus e os árabes. Paradoxalmente, tal espaço, no entanto, não deixa de ser elaborado em meio a uma linguagem que insiste e que se organiza sobre a lógica do "isto é" (FISCHER, 2006).

Em Nascidos em Bordéis, a imagem da criança é constituída junto à pobreza e ao descaso, mas também junto a folhas de contato, à escolha desta ou daquela imagem que elas mesmas produziram a partir de máquinas fotográficas simples. Crianças que ganham visibilidade não só pelo documentário, mas também pela exposição fotográfica das imagens que fizeram e que fora organizada por Zana, a fotógrafa-diretora. Visibilidade de si e de suas imagens, que chegam a ganhar a primeira página do mais importante jornal indiano. Olhamos para elas e, paralelamente, somos conduzidos a olhar aquilo que elas selecionaram, recortaram, compuseram. Seu encontro, portanto, é com a arte. Um encontro igualmente preparado, esperado, curioso, expresso pela excitação com que vão até o zoológico, entulhadas dentro um mesmo táxi, ou no ônibus a caminho da imensidão do mar.

Existências que ganham visibilidade por se chocarem talvez não só com o poder, mas, especialmente, com a vontade de saber (FOUCAULT, 2003). Vontade de saber, de um lado, das culturas que a criaram. Por outro, daqueles (nós?) que as olha. Que vidas são essas que teimam em (querer) sair da condição a que foram predestinadas? Que vidas são essas que ultrapassam a pobreza e a guerra para tornarem-se mais, para tornarem-se, elas mesmas, corpo-curiosidade, mesmo cercadas pelo medo?

Faço questão de usar a palavra espaço, pois, de fato, ela é o pano de fundo que sustenta os dois documentários. Em Promessas de um Novo Mundo, é em função do espaço, do território, que a narrativa (e a história) 
se concentra. Espaço é o tema dos depoimentos. É o que divide opiniões e corpos. O espaço é controlado e atribuído a um e a outro povo pelas páginas do Alcorão ou pelo papel enrolado da Torá, mas também pelo exército armado israelense. É o que separa e o que dificulta a possibilidade do encontro (ao final do filme, o menino árabe diz: "se não fosse pelos postos de fiscalização, poderíamos ter mais amigos”). O espaço é o que separa israelenses e árabes entre cidadãos e refugiados.

Em Nascidos em Bordéis, o espaço é delimitado pelos quartos sombrios e vetustos das prostitutas; é o espaço dividido entre as mães e os "homens maus" que as frequentam, homens que bebem, que fumam, que, muitas vezes, as espancam e a quem as crianças têm de servir, seja para comprar cigarros ou para comprar curry às três horas da manhã. $\mathrm{O}$ espaço é também o da fuga deste para um outro, talvez o da escola ou o do telhado do prédio, para onde as crianças fogem enquanto a mãe trabalha. O espaço é o que separa os moradores do bairro (homens, mulheres, crianças) do "resto", em outras palavras, da própria cidade: espaço entre cidadãos de direitos e subcidadãos.

Não por acaso, a escola tem uma importância fundamental tanto em um filme quanto no outro. Em Nascidos em Bordéis, isso é mais evidente. A escola é a possibilidade de as crianças terem "outra vida". A escola aqui é quase o lugar de exílio: confinadas, elas têm menos chances de estar em contato com a família e, portanto, com a perpetuação daquela vida indigna. Em Promessas, a escola é o lugar em que o mero desenho infantil expressa muito mais do que aquilo que efetivamente "sentem" (como se sabe, o ato de desenhar vem, há anos, sendo resumido a isso na escola). O desenho é o propulsor de perguntas e de respostas: mais do que jogo de saber-não saber, é o jogo do confirmar e reafirmar o que já está em evidência. O professor árabe pergunta a seus alunos, mostrando-lhes uma figura: "Esse cervo gosta mais da liberdade ou do cativeiro? E você? Gosta mais da liberdade? As crianças da Palestina vivem em liberdade? Quem pode fazer um desenho mostrando o que sente? Você é livre como esse cervo ou há algo que atrapalha sua liberdade?". Um dos alunos vai até o quadro e explica o desenho que fez: "Esta é uma criança com uma pedra dizendo: vou matar eles. A outra criança está chorando: mataram minha mãe, pai e irmã, que Deus amaldiçoe eles". O tapinha nas costas que recebe enfatiza não a excelência de uma pueril e estereotipada árvore verde com o tronco marrom, mas a certeza de que a morte é a única solução. 
A escola constitui-se, assim, como espaço de resistência, certamente bastante diferenciado das nossas noções de resistência. A noção de resistência que organizamos para o conceito de escola choca-se com aquelas formuladas pelos filmes: o que se ensina é, num filme, a diferença radical entre "nós" e "eles"; no outro, mais do que pensar num futuro melhor, a escola é, antes de mais nada, a distância imediata, possível e desejável de um ambiente assolador. Resistência torna-se, em função disso, sinônimo de nada menos do que "sobrevivência".

Por mais que, em Nascidos em Bordéis, haja um quê de salvacionismo, da fotógrafa que busca, para além das aulas de fotografia, uma escola para cada uma das crianças, há também algo que não se resume na alegria óbvia de "saírem daquela vida". Acompanhamos a sua busca ávida, que implica, diz ela, atender aos "pedidos de ajuda" feitos a ela pelas crianças. Zana vai de escola em escola, acompanha todos os passos do processo das inscrições, organiza detalhadamente desde o preenchimento da documentação à sessão de fotografias 3X4. Enquanto fala ao celular com um amigo, observamos seu desespero frente ao burocrata do cartório ou quando descobre que o aceite das crianças depende do resultado negativo em testes de HIV. Incansável, ela agenda os exames, recebe os resultados e comemora que nenhuma das crianças é portadora do vírus. Uma grande parte do filme é dedicada a esse empenho quase épico, que mescla desde as providências burocráticas às conversas de convencimento com cada uma das famílias. No entanto, há algo mais do que a comemoração da lógica sustentada pela chance de a escola fornecer novas possibilidades. As crianças são confrontadas com o fato de que essas "novas possibilidades" significam também estarem distantes das mães, de casa (seja esta a casa suja, na qual convivem com estranhos, ratos e restos de comida pelo chão): o que, para a fotógrafa, é a "solução", para as crianças é também saudade, ausência, receio de adentrarem em um universo inteiramente diferente. Os momentos são atravessados pela dúvida e até mesmo pelo descontentamento por parte das crianças. Não é sem relações de força, portanto, que se dá a proposta de nova escola. A fotógrafa alerta o menino Avijit de que a nova escola será a "única chance dele na vida". Por outro lado, para além do amanhã e do futuro aparentemente promissor, ele insiste, por um momento, em dizer que prefere ficar na escola em que está do que ter de recuar duas séries, como talvez exija a nova. 
O que tais considerações mostram é justamente a traição entre palavras e coisas; são instabilidades e conflitos o que crianças colocam em jogo no momento em que recebem seu feixe de luz pela câmera cinematográfica. É por meio do espaço vazio instaurado que elas (nos) escapam: não se resumem ao descontentamento com futuro a que são destinadas, nem à alegria certa daquele que agora são convidadas a assumir. Antes disso, as crianças se constituem num lugar incerto e intermediário, qual seja, aquele que cinde a afirmação do "isto é".

\section{Considerações finais}

No célebre texto "A vida dos homens infames", Foucault (2003) mostra-se fascinado por um pequeno conjunto de vidas ínfimas, narradas apenas por meio de algumas páginas, às vezes até frases, mas que alcançam uma intensidade impossível de apreender. Trata-se das lettres de cachet. documentos emitidos em nome e para o rei, datados em sua maioria dos séculos XVII e XVII e que tinham como objetivo a prisão, o internamento de indivíduos, cujos comportamentos e vidas tramam-se em função de uma única prerrogativa, a de serem “indesejáveis". Denúncias e queixas sobre devassos, libertinos, escandalosos, ladrões, ateus; textos que se constituíam como uma parte mínima daquelas vidas, mas que, exatamente por isso, as ataram à sua (in)felicidade, à sua loucura e também à sua visibilidade imediata. Para o autor, não importa se as palavras descritas por aqueles documentos eram falsas, enganosas, injustas: importa que por meio delas homens e mulheres viveram, morreram e ganharam um outro tipo de visibilidade muito aquém daquela advinda de sua genialidade, de seu heroísmo, de seu nascimento ou de sua riqueza material. Aquilo que arranca essas existências "da noite" (FOUCAULT, 2003) é o encontro momentâneo com o poder, é o fato de se defrontarem com regimes de disciplinamento. Jogo paradoxal que, no intuito de querer aniquilar essas vidas, as faz justamente sobreviverem até hoje. É por meio das palavras precárias que as descreveram para que tivessem um fim que aquelas vidas persistem e insistem em manifestar sua ira, sua aflição, a ponto de continuarem divagando, senão mais lá, pelo menos aqui, entre nós.

Rosa Fischer (2006) atualiza a discussão de Foucault ao pensar, hoje, nos "meninos infames de Cidade de Deus" (FISCHER, 2006, p. 56). 
De fato, as denúncias de infâmia atualmente, em pleno no século XXI, dispõem de uma rede de comunicação seguramente muito mais ampla. Para a autora, outras e novas lógicas de exclusão e de exposição de existências "indesejáveis" são tramadas; lógicas distantes em cerca de cinco ou seis séculos, mas que não se excluem e não se apagam e, consequentemente, encontram outras formas de se exercer. De personagens de livro, meninos de 8 a 20 anos, moradores da favela e vizinhos do tráfico, passam a protagonistas de um filme (Cidade de Deus), disseminam-se, multiplicam-se e ecoam nos mais diversos aparatos midiáticos, com diferentes roupagens - não se trata mais de discursos raros como aqueles descritos por Foucault, mas prolixos, que não cessam de tentar cercar os infames, seja no filme ficção, no documentário, nas páginas do jornal ou no horário nobre de domingo à noite. Apesar disso, esses corpos-resistência não se cansam de escapar: "por mais que haja semelhança com a realidade, há sempre outras relações sugeridas pelo que vemos e ouvimos" (FISCHER, 2006, p. 65).

Neste texto, busquei analisar o conceito de imagem documental a partir de dois materiais, que, igualmente, contemplam "vidas infames". Crianças que estariam fadadas a permanecer na invisibilidade do grande conjunto que as cerca (“judeus", “árabes”, “indianos”) são trazidas até nós por meio de imagens que, por mais que pretendam, por vezes, atá-las à lógica imediata entre palavras e coisas, mostram também sua dispersão. Entendo que, mais do que fazer visível um conjunto de depoimentos de crianças árabes, judias e indianas, tais materiais ocupam-se de uma "dramaturgia do real" (FOUCAULT, 2003). Percorrendo essas "crianças infames", cujo choque entre as imagens e suas vidas produz em nós um misto "de beleza e de terror" (FOUCAULT, 2003, p. 206), procurei pensar em que medida e por quais caminhos a linguagem cinematográfica e as existências que pulsam na superfície-tela, em seu cotejo, nos mostram vidas singulares que não se resumem a um mero "isto é". Existências curiosas e humanas que, em se tratando de criança, não se limitam a serem descritas por universalidades que as cercam (seja por instaurarem um espaço incerto entre a conformidade e a inconformidade com seu futuro, seja por desestabilizarem a alegria óbvia de sua reversão, seja na negação e, por que não dizer?, até mesmo na afirmação de uma ingenuidade pueril, de afeto fácil). Vidas que, portanto, não podem ser tomadas a partir de uma leitura linear, mas no interior de contradições, paradoxos e incongruências, 
nem por isso menos "verdadeiras", menos "reais". Vidas, portanto, que chegam até nós, nos olham e nos questionam em sua "medonha ou lamentável grandeza" (FOUCAULT, 2003).

Afirmar que o documentário não traz ou guarda em si "a" verdade ou que ele não captura "o" real não significa, de modo algum, desvalorizar ou condenar sua organização particular. O que importa aqui é trazer para a educação um debate contemporâneo sobre as imagens que nos cercam cotidianamente; ou seja, questionar elementos de uma linguagem específica que, muitas vezes, nos conduz a pensar que seria mais verídica, mais real, do que outras. Promessas de um Novo Mundo e Nascidos em Bordéis foram tomados, neste texto, como outra forma de "real" (nem mentirosa, nem "verdadeira"), afinal, antes de mais nada, não estamos lidando com "representação", mas, acima de tudo, com criação, com algo que se inventa - e que, neste caso, tem relação com o ato de dar visibilidade ao que há de singular na imagem da criança. 


\section{Referências}

DI TELLA, Andrés. O documentário e eu. In: MOURÃO, Maria Dora e LABAKI, Amir (Orgs.). O cinema do real. São Paulo: Cosac Naify, 2005. p. 68-81.

FISCHER, Rosa Maria Bueno. Foucault e os meninos infames de Cidade de Deus. Revista Educação - Especial Foucault Pensa a Educação, São Paulo, n. 3, p. 56-65, 2006.

FOUCAULT, Michel. A vida dos homens infames. In: FOUCAULT, Michel. Ditos e escritos III. Estratégia, poder-saber. Rio de Janeiro: Forense Universitária, 2001. p. 203-222. GODARD, Jean-Luc. Jean-Luc Godard par Jean-Luc Godard. Paris: Etoile, 1985.

KEHL, Maria Rita. Um épico de vidas infames. Folha de S.Paulo, São Paulo, 13 de novembro de 2005, Caderno Mais!. p. 1. Disponível em: <http://www1.folha.uol.com.br/fsp/mais/fs1311200504.htm>. Acessado em agosto de 2007.

MAXIMENT, Jocelyn. Est-ce ainsi que les hommes vivent? Ou le mentir-vrai du documentariste. La voix du regard - Revue littéraire sur les arts de l'image. Numéro spécial: Croire et faire croire, Ecole Normale Supérieure de Fontenay, n. 16, p. 165-179, automne, 2003.

NICHOLS, Bill. Introdução ao documentário. Campinas: Papirus, 2005.

RABIGER, Michael. Uma conversa com professores e alunos sobre a realização de documentários. In: MOURÃO, Maria Dora e LABAKI, Amir (Orgs.). O cinema do real. São Paulo: Cosac Naify, 2005. p. 52-67.

VERTOV, Dziga. NÓS - variação do manifesto; Resolução do conselho dos três; Nascimento do cine-olho; Extrato do ABC dos kinoks. In: XAVIER, Ismail (Org.). $A$ experiência do cinema - antologia. Rio de Janeiro: Edições Graal, 1983. p. 245-266.

XAVIER, Ismail. Cinema: revelação e engano. In: NOVAES, Adauto (Org.). O Olhar. São Paulo: Companhia das Letras, 1998. p. 367-383.

\section{Filmes citados}

COUTINHO, Eduardo. Jogo de Cena. Brasil, 105 min., 2007.

SHAPIRO, Justine e GOLDBERG, B. Z. Promessas de um novo mundo [Promises]. Estados Unidos/Israel, 106 min., 2001.

KAUFFMAN, Ross e BRISKI, Zana. Nascidos em bordéis [Born Into Brothels: Calcutta's Red Light Kids]. Estados Unidos, Índia, 85 min., 2004. 


\section{Notas}

$1 \mathrm{O}$ autor aqui usa a expressão régime de croyance para assinalar a importância das relações entre as imagens de um mesmo filme (muito mais do que sua identificação imediata com um gênero ou outro) para a produção do "verdadeiro". A expressão aqui, portanto, não é a mesma empregada por Michel Foucault (regime de vérité) e, portanto, foi traduzida livremente como "regime de credibilidade" (e não como "regime de verdade").

2 A pesquisa da qual este trabalho deriva conta com financiamento do CNPq (Edital Universal, 2008).

Recebido: 06/10/2009

Aprovado: 04/05/2010

Contato:

Universidade Luterana do Brasil Programa de Pós-Graduação em Educação

Av. Farroupilha, 8001

Prédio 14, sala 217 - São Luís

Canoas - RS

CEP $92450-900$ 